Abstracted/indexed in Academic Search Complete, Asia Journals Online, Bangladesh Journals Online, Biological Abstracts, BIOSIS Previews, CAB Abstracts, Current Abstracts, Directory of Open Access Journals, EMBASE/Excerpta Medica, Google Scholar, HINARI (WHO), International Pharmaceutical Abstracts, Open J-gate, Science Citation Index Expanded, SCOPUS and Social Sciences Citation Index;

\title{
Isolation of flavonoids from onion skin and their effects on K562 cell viability
}

\author{
Guo-Qing Shi' ${ }^{1}$ Jing Yang ${ }^{1}$, Jiang Liu ${ }^{2}$, Sheng-Nan Liu ${ }^{1}$, Han-Xue Song ${ }^{1}$, Wen-En Zhao ${ }^{3}$ \\ and Yan-Qi Liu'
}

${ }^{1}$ School of Food and Bioengineering, Zhengzhou University of Light Industry, Henan, Zhengzhou 450002 , P. R. China; ${ }^{2}$ National Engineering Laboratory for Further Processing of Wheat and Corn, Henan University of Technology, Henan, Zhengzhou 450 000, P. R. China; ${ }^{3}$ School of Chemical Engineering and Energy, Zhengzhou University, Henan, Zhengzhou 450 052, P. R. China.

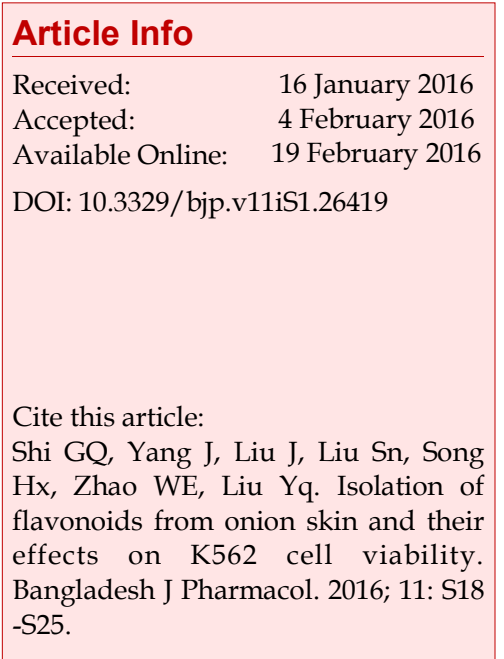

\begin{abstract}
To investigate the anti-proliferative activity of flavonoids from onion skins, extraction by $50 \%$ ethanol $(\mathrm{v} / \mathrm{v})$, soxhlet polar fractionation, $\mathrm{pH}$ gradient separation, thin-layer chromatography, and recrystallization methods were used to isolate and purify flavonoids from dry onion skins. Anti-proliferative activities of some flavonoids obtained on leukemia K562 cell line were determined by MTT assay. Results showed that flavonoids of onion skins were mainly in form of quercetin, kaempferol, isorhamnetin, apigenin-7-O- $\beta$-Dglucopyranoside, quercetin-3-O- $\beta$-D-glucopyranoside, kaempferol-7-O- $\beta$-Dglucopyranoside and rutin. Quercetin and kaempferol decreased K562 cell viability, and quercetin had stronger effect. However, isorhamnetin and rutin exhibited certain proliferation-promoting effects. It suggests that ortho hydroxyl groups on B ring of onion flavonoids might be the key structural elements of their cytotoxic effects on K562 cells, and hydroxyl groups in position 3 or carbonyl groups in position 4 might be one of the structural effect elements.
\end{abstract}

\section{Introduction}

Onion (Allium cepa L.) is considered to be one of the world's oldest cultivated vegetable, and contains high level of dietary flavonoids (Slimestad et al., 2007), which are present in much higher concentrations in the onion skin than they are in the fleshy bulb (Kim and Kim, 2006; Yao et al., 2004; Sellappan and Akoh, 2002). There is a growing body of evidence indicating that flavonoids may exhibit health-promoting effects (Griffiths et al., 2002).

The results of several studies have shown that the physiological functions of flavonoids are dependent on

This paper was presented in the 3rd International Conference on Biomedicine and Pharmaceutics in Zhuhai, China, on December 11-13, 2015. their structures, because flavonoids with different structures exhibit a variety of different biological activities (Kefalas et al., 2006).

The isolation and identification of flavonoids from onion skin would not only enhance our understanding of the material basis for their biological activities, but could also provide a theoretical basis for the utilization of these compounds in a number of other areas of research.

Significant research efforts have been directed towards the characterization of onion and onion skin flavonoids during the last decade (Soltoft et al., 2009; PérezGregorio et al., 2010; Kiassos, et al., 2009; Jin, et al., 2011) which has led to a significant increase in our understanding of these compounds. Despite these 
studies, information pertaining to the systematic isolation and identification of flavonols from discarded onion skin remains scarce.

\section{Materials and Methods}

Dry red onion skins were collected from Zhengzhou North Central Vegetable Wholesale Market, China. Onion skin powder was obtained through the sequential cleaning, drying and grounding of the onion skins.

\section{Extraction}

Two hundred grams of onion skin powder was extracted with $6 \mathrm{~L}$ of $50 \%$ aqueous ethanol at $72^{\circ} \mathrm{C}$ for 2 hours in a water bath. The resulting extract was then cooled to ambient temperature and filtered through filter paper. This procedure was repeated two times and the combined extracts were concentrated under vacuum on a rotary evaporator near to cream, which was absorbed onto diatomaceous earth and dried in the air.

\section{Soxhlet polar fractionation}

The dried diatomaceous earth samples were sequentially extracted with petroleum ether, diethyl ether, and ethyl acetate using a soxhlet extractor. Each solvent extraction procedure was conducted for 12 hours. The petroleum ether phase was discarded, whereas the diethyl ether and ethyl acetate extracts were collected for further processing.

\section{pH gradient separation}

The diethyl ether phase was extracted three times with $2 \%(\mathrm{w} / \mathrm{v}) \mathrm{NaHCO}_{3}$ solution, and the $\mathrm{pH}$ of the combined aqueous extracts was adjusted with concentrated hydrochloric acid to $\mathrm{pH} 2$. The acidified aqueous was then extracted with diethyl ether before being evaporated to dryness under vacuum to give the $\mathrm{NaHCO}_{3}$ components of the diethyl ether phase. The organic phase was sequentially extracted with $5 \%(\mathrm{w} / \mathrm{v})$ $\mathrm{Na}_{2} \mathrm{CO}_{3}$ and $1 \%(\mathrm{w} / \mathrm{v}) \mathrm{NaOH}$ solutions to give the corresponding diethyl ether phase components. The ethyl acetate phase was subjected to the same separation method to give the $\mathrm{NaHCO}_{3}, \mathrm{Na}_{2} \mathrm{CO}_{3}$, and $\mathrm{NaOH}$ components of the ethyl acetate phase.

\section{Isolation}

The $\mathrm{NaOH}$ components of the diethyl ether and ethyl acetate phases were discarded because they contained very low levels of flavonoids. The flavonoids in the $\mathrm{NaHCO}_{3}$ and $\mathrm{Na}_{2} \mathrm{CO}_{3}$ components of the diethyl ether and ethyl acetate phases were isolated by preparative TLC (developing solvents: toluene/ethyl, formate/ formic acid, and toluene/ethyl formate/ethanol/formic acid) and recrystallized from chloroform and methanol to give seven flavonoids (Table I).

\section{Identification reactions}

$\mathrm{HCl}-\mathrm{Mg}$ reaction was used for the identification of the flavonoids. Briefly, a few milligrams of $\mathrm{Mg}$ powder were added to $1 \mathrm{~mL}$ ethanol solutions of the samples $(0.1 \mathrm{mg} / \mathrm{mL})$. A few drops of concentrated hydrochloric were added to the solutions, and the resulting mixtures were heated in a water bath when necessary. The formation of a red or purple color indicated the occurrence of a positive reaction.

Molisch reaction was used for the identification of glycosidic units. Solution I was made as follows: anaphthol (1 g) was accurately weighed into a volumetric flask and dissolved and diluted to $10 \mathrm{~mL}$ with $75 \%$ ethanol. Solution II was concentrated sulfuric acid. Two or three drops of solution I were added to $1 \mathrm{~mL}$ of ethanol or an aqueous solution of the flavonoid sample, and the resulting solution was thoroughly mixed. A small amount of solution II was then slowly added to the sample mixture along the wall of the tube. Notably, the interface between the samples solution and solution

Table I

Flavonoids isolated from onion skins

\begin{tabular}{|lll|}
\hline Source & Number & Compound name \\
\hline The $\mathrm{NaHCO}_{3}$ components of diethyl ether phase & Compound 1 & Isorhamnetin \\
& Compound 2 & Quercetin \\
& Compound 3 & Kaempferol \\
The $\mathrm{Na}_{2} \mathrm{CO}_{3}$ components of diethyl ether phase & Compound 5 & Quercetin-3-O- $\beta$-D-glucopyranoside \\
The $\mathrm{NaHCO}_{3}$ components of ethyl acetate phase & Compound 7 & Rutin \\
& Compound 2 & Quercetin \\
The $\mathrm{Na}_{2} \mathrm{CO}_{3}$ components of ethyl acetate phase & Compound 4 & Apigenin-7-O- $\beta$-D-glucopyranoside \\
& Compound 6 & Kaempferol-7-O- $\beta$-D-glucopyranoside \\
\hline
\end{tabular}


II became purple in color for a positive reaction.

\section{Cell culture and drug treatment}

K562 cells were cultured in RPMI 1640 medium supplemented with decomplemented fetal bovine serum $(10 \%, \mathrm{v} / \mathrm{v})$, penicillin $(100 \mathrm{IU} / \mathrm{mL})$, and streptomycin $(100 \mu \mathrm{g} / \mathrm{mL})$ in a humidified incubator under $5 \%$ $\mathrm{CO}_{2}$ and $95 \%$ air at $37^{\circ} \mathrm{C}$.

The flavonoids were added to the cells using dimethyl sulfoxide (DMSO) as a solvent. The concentrations of the DMSO solutions were adjusted to be the same in all of experiments, and the final concentrations were never greater than $0.5 \%(\mathrm{v} / \mathrm{v})$. The control group received the same amount of DMSO without any flavonoids.

Cell viability was measured using an MTT assay. Briefly, the K562 cells were seeded into 96-well culture plates and cultured with various concentrations of the different flavonoids for 72 hours at $37^{\circ} \mathrm{C}$. After the treatment, each cell was treated with an MTT solution to a final concentration $500 \mu \mathrm{g} / \mathrm{mL}$, and the plates were then incubated for 4 hours at $37^{\circ} \mathrm{C}$. At the end of the incubation period, the media was carefully removed from each well and replaced with $100 \mu \mathrm{L}$ of DMSO. The resulting mixtures were then gently agitated to allow for the solubilization of the precipitated formazan crystals, and the absorbance values of the cells were then measured at $570 \mathrm{~nm}$ using a Bio-Rad model 680 microplate reader (Richmond, CA, USA). The absorbance values of the treated cells were compared with those of the controls, where the cells were considered to be $100 \%$ viable. The rate of inhibition could then be calculated using the following equation.

Inhibition rate $(\%)=(1-$ absorbance of treatment groups / absorbance of control groups) $\times 100 \%$.

\section{Results}

\section{Structures of isolated compounds}

Seven flavonoids were isolated from the dry onion skins evaluated in the current study (Figure 1). The structures of these compounds were elucidated as follows:

Compound 1: Physical form, yellow powder; hydrochloric acid-Mg reaction, positive; Molisch reaction, negative. These results suggested that compound 1 was a flavonoid without any glycosidic groups. ESI-MS (Agilent 1100 LC-MSD-Trap-XCT, Agilent, Agilent Technologies Inc. SantaClara, California, USA) in the negative ion mode displayed a pseudomolecular ion peaks with an $m / z$ value of 315 , corresponding to [M-H] -. Elemental analysis (Flash EA1112 elemental analyzer, Thermo Electron SPA Company, USA) showed that the amounts of $\mathrm{C}$ and $\mathrm{H}$ in compound 1 were 60.44 and $3.83 \%$, respectively. Taken together with the NMR results (Avance-300 NMR spectrometer, Bruker, Bruker Optics, Germany), the molecular formula of compound 1 was determined to be $\mathrm{C}_{16} \mathrm{H}_{12} \mathrm{O}_{7}$. The Fourier transform infrared (FT-IR) spectrum (Nexus470 Fourier transform infrared spectrometer, Nicolet Instrument Company, USA) spectrum of compound 1 contained a broad peak at $3238 \mathrm{~cm}^{-1}$, as well as a much narrower C-O peak in the range of $1250-1050 \mathrm{~cm}^{-1}$, which were consistent with the presence of hydroxyl groups. Another peak was observed at $1656 \mathrm{~cm}^{-1}$, which was attributed to the stretching vibration of a carbonyl group. Several other peaks were observed at 1616, 1560, 1509 and $1446 \mathrm{~cm}^{-1}$, together with broader peaks over $3000 \mathrm{~cm}^{-1}$, which were attributed to an entitative phenyl ring structure. The peaks at 1616, 1509 and $1383 \mathrm{~cm}^{-1}$ could also be indicative of the presence of an oxygen heterocycle.

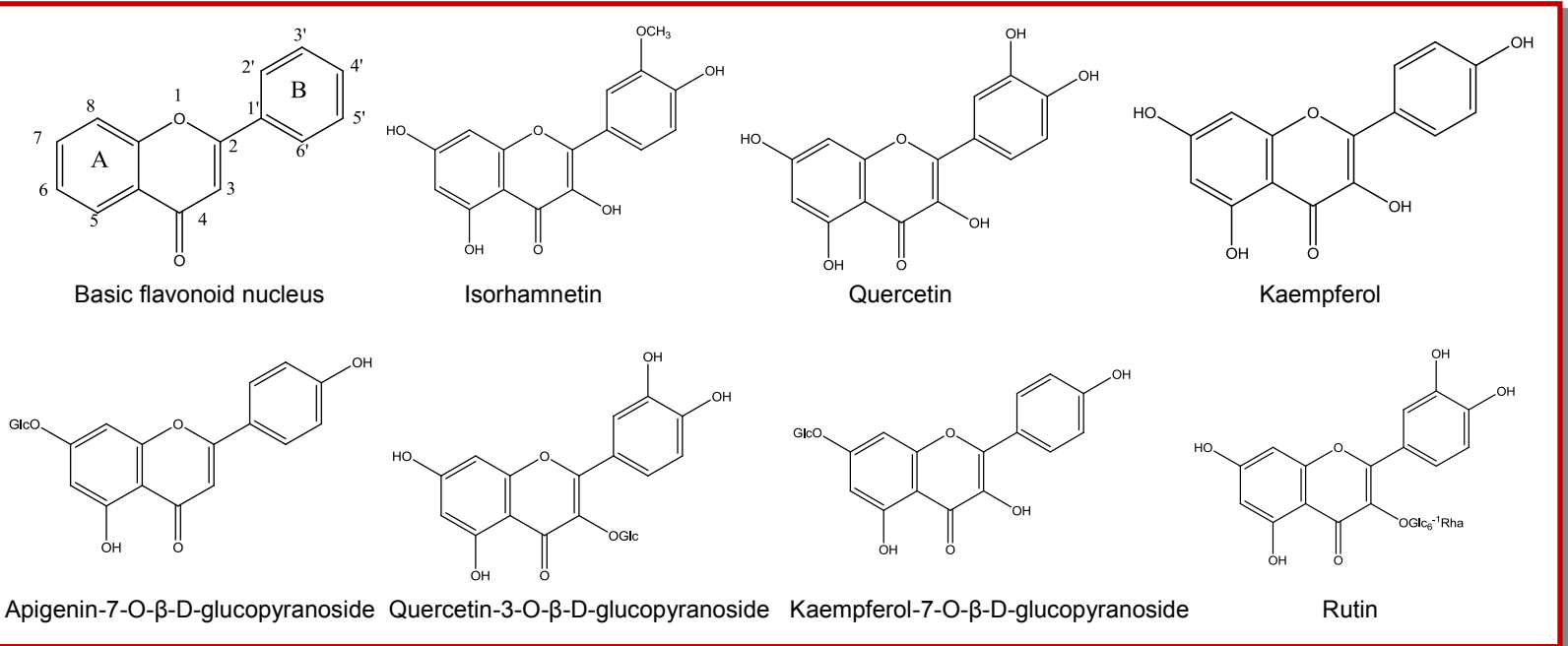

Figure 1: Structures of the flavonoids obtained from onion skins 
NMR data: ${ }^{1} \mathrm{H}-\mathrm{NMR}\left(300 \mathrm{MHz}, \mathrm{DMSO}-\mathrm{d}_{6}\right) \delta: 12.48(1 \mathrm{H}$, s, 5-OH), $10.74(1 \mathrm{H}, \mathrm{s}, 7-\mathrm{OH}), 9.75(2 \mathrm{H}, \mathrm{s},-\mathrm{OH}), 7.76(1 \mathrm{H}$, d, $\left.J=1.7 \mathrm{~Hz}, \mathrm{H}-2^{\prime}\right), 7.69\left(1 \mathrm{H}, \mathrm{dd}, J=1.7,8.1 \mathrm{~Hz}, \mathrm{H}-6^{\prime}\right)$, $6.95\left(1 \mathrm{H}, \mathrm{d}, J=8.5 \mathrm{~Hz}, \mathrm{H}-5^{\prime}\right), 6.49(1 \mathrm{H}, \mathrm{d}, J=2.0 \mathrm{~Hz}, \mathrm{H}-$ 8), $6.20(1 \mathrm{H}, \mathrm{d}, J=1.7 \mathrm{~Hz}, \mathrm{H}-6), 3.85\left(3 \mathrm{H}, \mathrm{s},-\mathrm{OCH}_{3}\right) ;{ }^{13} \mathrm{C}-$

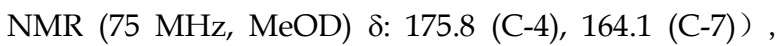
161.1 (C-9), 156.2 (C-5), 148.4 (C-3'), 147.6 (C-2), 146.8 (C $\left.-4^{\prime}\right), 135.8$ (C-3), 122.2 (C-1'), 120.8 (C-6'), 115.6 (C-2'), 111.8 (C-5'), 102.8 (C-10), 98.8 (C-6), 94.0 (C-8), 55.2 (3$\left.\mathrm{OCH}_{3}\right)$. These data were found to be consistent with those reported in the literature for isorhamnetin (Park and Lee, 1996; Bonaccorsi et al., 2005; Ning, 2000; Fossen and Abdersen, 2006; Markham and Geiger, 1994; Stochmal et al., 2001), and so compound 1 was identified as isorhamnetin.

Compound 2: Physical form, yellow powder; hydrochloric acid-Mg reaction, positive; Molisch reaction, negative. The results suggested that compound 2 could be a flavonoid without any glycoside functionality. ESIMS analysis of compound 2 in the negative ion mode revealed a pseudomolecular ion peak with an $\mathrm{m} / \mathrm{z}$ value of 301, corresponding to $[\mathrm{M}+\mathrm{H}]-$. Elemental analysis showed that the amounts of $\mathrm{C}$ and $\mathrm{H}$ in compound 2 were 59.61 and $3.32 \%$, respectively. Taken together with the NMR results, these data suggested that the molecular formula of compound 2 was $\mathrm{C}_{15} \mathrm{H}_{10} \mathrm{O}_{7}$. FT-IR analysis revealed peaks at 3318 and $1250-1050 \mathrm{~cm}^{-1}$, which were consistent with the presence of hydroxyl groups. The peak at $1663 \mathrm{~cm}^{-1}$ was attributed to the stretching vibration of a carbonyl group. Several other peaks were observed at 1611, 1561, 1522 and $1450 \mathrm{~cm}^{-1}$, which were consistent with the presence of a phenyl ring skeleton. The peaks observed at 1611, 1522 and $1408 \mathrm{~cm}^{-1}$ also suggested the presence of an oxygencontaining heterocycle.

NMR data: ${ }^{1} \mathrm{H}-\mathrm{NMR}(300 \mathrm{MHz}, \mathrm{DMSO}-\mathrm{d} 6)$ ): $12.50(1 \mathrm{H}$, s, 5-OH), $10.83(1 \mathrm{H}, \mathrm{s}, 7-\mathrm{OH}), 9.38(3 \mathrm{H}, \mathrm{s},-\mathrm{OH}), 7.67$ $\left(1 \mathrm{H}, \mathrm{d}, J=2.1 \mathrm{~Hz}, \mathrm{H}-2^{\prime}\right), 7.53(1 \mathrm{H}, \mathrm{dd}, J=7.2,1.9 \mathrm{~Hz}, \mathrm{H}-$ $\left.6^{\prime}\right), 6.88\left(1 \mathrm{H}, \mathrm{d}, J=8.5 \mathrm{~Hz}, \mathrm{H}-5^{\prime}\right), 6.40(1 \mathrm{H}, \mathrm{d}, J=1.7 \mathrm{~Hz}$, $\mathrm{H}-8), 6.18(1 \mathrm{H}, \mathrm{d}, J=1.7 \mathrm{~Hz}, \mathrm{H}-6)$; ${ }^{13} \mathrm{C}-\mathrm{NMR}(75 \mathrm{MHz}$,

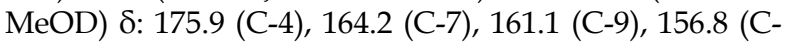
5), 147.4 (C-2), 146.6 (C-4'), 144.8 (C-3'), 135.7 (C-3), 122.7 (C-1'), 120.3 (C-6'), 114.8 (C-5'), 114.5 (C-2'), 103.1 (C-10), 97.8 (C-6), 93.0 (C-8). These data were consistent with those reported in the literature for quercetin (Rhodes and Price, 1996; Fossen et al., 1998; Lee et al., 2008; Ly et al., 2005; Ning, 2000; Fossen and Andersen, 2006; Markham and Geiger, 1994; Stochmal et al., 2001), and so compound 2 was identified as quercetin.

Compound 3: Physical form, yellow powder; hydrochloric acid-Mg reaction, positive; Molisch reaction, negative. These results suggested that compound 3 was a flavonoid without any glycoside functionality. ESI-MS analysis in the negative ion mode revealed a pseudomolecular ion peaks with an $m / z$ value of 285 , corresponding to $[\mathrm{M}-\mathrm{H}]^{-}$. Elemental analysis showed that the amounts of $\mathrm{C}$ and $\mathrm{H}$ in compound 3 were 61.91 and $3.63 \%$, respectively. Taken together with the NMR results, these data suggested that the molecular formula of compound 3 was $\mathrm{C}_{15} \mathrm{H}_{10} \mathrm{O}_{6}$. The FT-IR spectrum of compound 3 contained peaks at 3318 and $1250-1050 \mathrm{~cm}^{-}$ 1 , which were consistent with the existence of hydroxyl groups. A peak was also observed at $1661 \mathrm{~cm}^{-1}$, which was attributed to the stretching vibration of a carbonyl group. The vibrational absorption peaks observed at $1613,1569,1508$ and $1438 \mathrm{~cm}^{-1}$ were consistent with the presence of a phenyl ring skeleton, and the peaks at 1611, 1522 and $1408 \mathrm{~cm}^{-1}$ indicated the presence of an oxygen-containing heterocycle.

NMR data: ${ }^{1} \mathrm{H}-\mathrm{NMR}\left(300 \mathrm{MHz}, \mathrm{DMSO}-\mathrm{d}_{6}\right) \delta: 12.50(1 \mathrm{H}$, s, 5-OH), $10.83(1 \mathrm{H}, \mathrm{s}, 7-\mathrm{OH}-7), 9.38(3 \mathrm{H}, \mathrm{s},-\mathrm{OH}), 7.67$ $\left(1 \mathrm{H}, \mathrm{d}, J=2.1 \mathrm{~Hz}, \mathrm{H}-2^{\prime}\right), 7.53(1 \mathrm{H}, \mathrm{dd}, J=7.2,1.9 \mathrm{~Hz}, \mathrm{H}-$ $\left.6^{\prime}\right), 6.88\left(1 \mathrm{H}, \mathrm{d}, J=8.5 \mathrm{~Hz}, \mathrm{H}-5^{\prime}\right), 6.40(1 \mathrm{H}, \mathrm{d}, J=1.7 \mathrm{~Hz}$, $\mathrm{H}-8), 6.18(1 \mathrm{H}, \mathrm{d}, J=1.7 \mathrm{~Hz}, \mathrm{H}-6)$; ${ }^{13} \mathrm{C}-\mathrm{NMR}(75 \mathrm{MHz}$, MeOD) ס: 175.9 (C-4), 164.2 (C-7), 161.1 (C-9), 156.8 (C5), 147.4 (C-2), 146.6 (C-4'), 144.8 (C-3'), 135.7 (C-3), 122.7 (C-1'), 120.3 (C-6'), 114.8 (C-5'), 114.5 (C-2'), 103.1 (C-10), 97.8 (C-6), 93.0 (C-8). These data were found to be consistent with those reported in the literature for kaempferol (Ning, 2000; Fossen and Andersen, 2006; Markham and Geiger, 1994; Stochmal et al., 2001), and so compound 3 was identified as kaempferol.

Compound 4: Physical appearance, yellow powder; hydrochloric acid-Mg reaction, positive; Molisch reaction, positive. These results suggested that compound 4 was a flavonoid glycoside.

NMR data: ${ }^{1} \mathrm{H}-\mathrm{NMR}\left(300 \mathrm{MHz}, \mathrm{DMSO}-\mathrm{d}_{6}\right) \delta: 7.97(2 \mathrm{H}$, $\left.\mathrm{d}, J=9.4 \mathrm{~Hz}, \mathrm{H}-2^{\prime}, 6^{\prime}\right), 6.95\left(2 \mathrm{H}, \mathrm{d}, J=8.3 \mathrm{~Hz}, \mathrm{H}-3^{\prime}, 5^{\prime}\right)$, 6.88 (1H, s, H-3), 6.83 (1H, s, H-8), 6.44 (1H, s, H-6), 5.09 $(2 \mathrm{H}, \mathrm{d}, J=6.9 \mathrm{~Hz}, \mathrm{H}-1 ")$; ${ }^{13} \mathrm{C}-\mathrm{NMR}\left(75 \mathrm{MHz}, \mathrm{DMSO}^{\left.-\mathrm{d}_{6}\right)}\right.$ ठ: 182.1 (C-4), 164.4 (C-2), 163.0 (C-7), 161.5 (C-5), 161.2 (C-4'), 157.0 (C-9), 128.7 (C-6'), 128.7 (C-2'), 121.1 (C-1'), 116.1 (C-3'), 116.1 (C-5'), 105.4 (C-10), 103.2 (C-3), 100.0 (C-1"), 99.6 (C-6), 94.9 (C-8), $77.3\left(\mathrm{C}-3^{\prime \prime}\right), 76.4\left(\mathrm{C}-5^{\prime \prime}\right), 73.2$ $\left(\mathrm{C}-2^{\prime \prime}\right), 69.6\left(\mathrm{C}-4^{\prime \prime}\right), 60.7$ (C-6"). These data were discovered to be consistent with those reported in the literature of apigenin-7-O- $\beta$-D-glucopyranoside (Ning, 2000; Fossen and Andersen, 2006; Markham and Geiger, 1994; Stochmal et al., 2001), and so compound 4 was identified as apigenin-7-O- $\beta$-D-glucopyranoside.

Compound 5: Physical form, yellow powder; hydrochloric acid-Mg reaction, positive; Molisch reaction, positive. These results suggested that compound 5 could be a flavonoid glycoside.

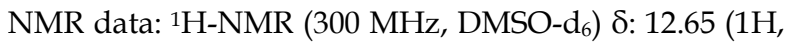
s, 5-OH-5), 9.0-11.0 (3H, br, $-\mathrm{OH}), 7.59(2 \mathrm{H}, \mathrm{d}, J=5.9$ $\left.\mathrm{Hz}, \mathrm{H}-2^{\prime}, 6^{\prime}\right), 6.85\left(1 \mathrm{H}, \mathrm{d}, J=8.9 \mathrm{~Hz}, \mathrm{H}-5^{\prime}\right), 6.41(1 \mathrm{H}, \mathrm{s}, \mathrm{H}-$ 8), $6.20(1 \mathrm{H}, \mathrm{d}, J=1.4 \mathrm{~Hz}, \mathrm{H}-6), 5.48(1 \mathrm{H}, \mathrm{d}, J=6.9 \mathrm{~Hz}, \mathrm{H}$ -1"); ${ }^{13} \mathrm{C}-\mathrm{NMR}$ (75 MHz, DMSO-d 6 ) $\delta: 177.5$ (C-4), 164.3 (C-7), 161.3 (C-5), 156.4 (C-2), 156.3 (C-9), 148.6 (C-4'), 144.9 (C-3'), 133.4 (C-3), 121.7 (C-6'), 121.3 (C-1'), 116.3 
(C-5'), 115.3 (C-2'), 104.1 (C-10), 100.9 (C-1"), 98.8 (C-6), 93.6 (C-8), 77.7 (C-3"), 76.6 (C-5"), $74.2\left(\mathrm{C}-2^{\prime \prime}\right), 70.0$ (C-4"), $61.1\left(\mathrm{C}-6^{\prime \prime}\right)$. These data were found to be consistent with those reported in the literature for quercetin 3-O- $\beta$-Dglucopyranoside (Park and Lee, 1996; Bonaccorsi et al., 2005; Lee et al., 2008; Ning, 2000; Fossen and Andersen, 2006; Markham and Geiger, 1994; Stochmal et al., 2001), and so compound 5 was identified as quercetin $3-O-\beta-D$ -glucopyranoside.

Compound 6: Physical form, yellow powder; hydrochloric acid-Mg reaction, positive; Molisch reaction, positive. These results suggested that compound 6 could be a flavonoid glycoside.

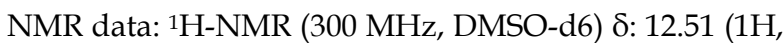
s, $-\mathrm{OH}), 10.16(1 \mathrm{H}, \mathrm{s},-\mathrm{OH}), 9.56(1 \mathrm{H}, \mathrm{s},-\mathrm{OH}), 8.09(2 \mathrm{H}$, $\left.\mathrm{d}, J=8.8 \mathrm{~Hz}, \mathrm{H}-2^{\prime}, 6^{\prime}\right), 6.95\left(2 \mathrm{H}, \mathrm{d}, J=8.8 \mathrm{~Hz}, \mathrm{H}-3^{\prime}, 5^{\prime}\right)$, $6.82(1 \mathrm{H}, \mathrm{d}, J=1.5 \mathrm{~Hz}, 8-\mathrm{H}), 6.44(1 \mathrm{H}, \mathrm{d}, J=1.7 \mathrm{~Hz}, \mathrm{H}-$ 6), $5.08\left(1 \mathrm{H}, \mathrm{d}, J=6.3 \mathrm{~Hz}, \mathrm{H}-1^{\prime \prime}\right) ;{ }^{13} \mathrm{C}-\mathrm{NMR}(75 \mathrm{MHz}$, DMSO-d $_{6}$ 176.1 (C-4), 162.8 (C-7), 160.4 (C-5), 159.4 (C4'), 155.8 (C-9), 147.6 (C-2), 136.1 (C-3), 129.7 (C-2'), 129.7 (C-6'), 115.5 (C-3'), 115.5 (C-5'), 104.8 (C-10), 100.9 (C-1"), 100.0 (C-1'), 98.8 (C-6), 94.5 (C-8), 77.2 (C-3"), 76.5 (C-5"), 73.2(C-2"), $69.7\left(\mathrm{C}-4^{\prime \prime}\right), 60.7\left(\mathrm{C}-6^{\prime \prime}\right)$. These data were found to be consistent with those reported in the literature for kaempferol-7-O- $\beta$-D-glucopyranoside (Ning, 2000; Fossen and Andersen, 2006; Markham and Geiger, 1994; Stochmal et al., 2001), and so compound 6 was identified as kaempferol-7-O- $\beta$-D-glucopyranoside.

Compound 7: Physical form, yellow powder; hydrochloric acid-Mg reaction, positive; Molisch reaction, positive. These results therefore suggested that compound 7 could be a flavonoid glycoside. ESI-MS analysis of compound 7 in the negative ion mode revealed a pseudomolecular ion peak with an $m / z$ value of 609, corresponding to [M-H]-. Elemental analysis showed that the amounts of $\mathrm{C}$ and $\mathrm{H}$ in compound 7 were 53.22 and $4.86 \%$, respectively. Taken together with the NMR results, these data suggested that the molecular formula of compound 7 was $\mathrm{C}_{27} \mathrm{H}_{30} \mathrm{O}_{16}$. The FT-IR spectrum of compound 7 contained a broad peak at $3423 \mathrm{~cm}^{-1}$ and a second peak at $1250-1050 \mathrm{~cm}^{-1}$, which indicated the presence of hydroxyl groups. A peak was also observed at $1656 \mathrm{~cm}^{-1}$, which was attributed to the stretching vibration of a carbonyl group. Several other vibrational absorption peaks were observed at 1601, 1574,1505 and $1456 \mathrm{~cm}^{-1}$, together with a shoulder peak at $3000 \mathrm{~cm}^{-1}$, which were consistent with an entitative phenyl ring skeleton. The peaks at 1601 and $1505 \mathrm{~cm}^{-1}$ were indicative of the presence of an oxygen-containing heterocycle. The peak at $1363 \mathrm{~cm}^{-1}$ was attributed to the stretching vibration of a methyl group.

NMR data: ${ }^{1} \mathrm{H}-\mathrm{NMR}\left(300 \mathrm{MHz}, \mathrm{DMSO}-\mathrm{d}_{6}\right) \delta: 12.61(1 \mathrm{H}$, s, 5-OH), 8.5-11.5 (1H, br, $-\mathrm{OH}), 7.54(2 \mathrm{H}, \mathrm{d}, J=7.5 \mathrm{~Hz}$, H-2', 6'), $6.84\left(1 \mathrm{H}, \mathrm{d}, J=8.4 \mathrm{~Hz}, \mathrm{H}-5^{\prime}\right), 6.38(1 \mathrm{H}, \mathrm{s}, \mathrm{H}-8)$, $6.19(1 \mathrm{H}, \mathrm{s}, \mathrm{H}-6), 5.34\left(2 \mathrm{H}, \mathrm{d}, J=7.1 \mathrm{~Hz}, \mathrm{H}-1^{\prime \prime}\right), 4.38(1 \mathrm{H}$, s, H-1"'), $0.99\left(3 \mathrm{H}, \mathrm{d}, J=6.1 \mathrm{~Hz}, \mathrm{H}-6^{\prime \prime \prime}\right) ;{ }^{13} \mathrm{C}-\mathrm{NMR}(75$
MHz, DMSO-d 6 ) ס: 177.5 (C-4), 164.3 (C-7), 161.4 (C-5), 156.8 (C-9), 156.8 (C-4'), 156.6(C-2), 144.9 (C-3'), 133.5 (C -3), 121.8 (C-6'), $121.3\left(\mathrm{C}-1^{\prime}\right), 116.4\left(\mathrm{C}-5^{\prime}\right), 115.4$ (C-2'), 104.1 (C-10), 101.3 (C-1"), 100.9 (C-1"'), 98.9 (C-6), 93.8 (C -8), 76.6 (C-3"), $76.1\left(\mathrm{C}-5^{\prime \prime}\right), 74.2\left(\mathrm{C}-2^{\prime \prime}\right), 72.0\left(\mathrm{C}-4^{\prime \prime \prime}\right), 70.7$ $\left(\mathrm{C}-3^{\prime \prime}\right), 70.5\left(\mathrm{C}-3^{\prime \prime \prime}\right), 70.2\left(\mathrm{C}-2^{\prime \prime \prime}\right), 68.4\left(\mathrm{C}-5^{\prime \prime \prime}\right), 67.2$ (C-6"), $17.9\left(\mathrm{C}-6^{\prime \prime}\right)$. These data were found to be consistent with those reported in the literature of rutin (Park and Lee, 1996; Ning, 2000; Fossen and Andersen, 2006; Markham et al., 1994; Stochmal et al., 2001), and so compound 7 was identified as rutin.

Isorhamnetin (17 mg), quercetin (64 mg), kaempferol (14 mg), apigenin-7-O- $\beta$-D-glucopyranoside $(3 \mathrm{mg})$, quercetin 3-O- $\beta$-D-glucopyranoside $(3 \mathrm{mg})$, kaempferol7-O- $\beta$-D-glucopyranoside $(2 \mathrm{mg}$ ) and rutin $(11 \mathrm{mg})$ were obtained from $200 \mathrm{~g}$ of dry onion skins using the extraction and isolation methods described above.

\section{Inhibitory effects of the flavonoids from onion skins towards the proliferation of $\mathrm{K} 562$ cells}

Although a wide range of flavonoids have recently reported to exhibit antitumor activities, inhibit the proliferation of leukemia cells, and induce cell apoptosis, none of these flavonoids have been reported to be nontoxic or even weakly toxic to normal human cells (Cárdenas et al., 2006; Shen et al., 2007). To evaluate the anti-proliferative activities of the flavonoids isolated from onion skins in the current study, we investigated the effects of isorhamnetin, rutin, quercetin, and kaempferol on the viability of chronic myelogenous leukemia K562 cells.

As shown in Figure 2, quercetin and kaempferol led to a significant reduction in the proliferation of the K562 cells. Furthermore, the anti-proliferative activity of quercetin was stronger than that of kaempferol when they were administered at the same concentration. Interestingly, however, isorhamnetin and rutin led to an increase in viability of the K562 cells.

\section{Discussion}

In this study, seven flavonoids were isolated from dry onion skins and evaluated in terms of their antiproliferative activity towards K562 cells. Although isorhamnetin and rutin exhibited certain proliferationpromoting effects, quercetin and kaempferol led to a significant decrease in the viability of K562 cells, with quercetin exhibiting the stronger effect of the two compounds. In terms of the structural features of these flavonols, the presence of an ortho hydroxyl group on the $\mathrm{B}$ ring or hydroxyl and carbonyl groups at the 3and 4-positions, respectively, were critical to the antiproliferative activity towards K562 cells.

As mentioned above, the mono- and diglucosides of quercetin account for up to $80 \%$ of the total flavonol 
content of onion skins (Rhodes and Price, 1996). Fossen et al. (1998) reported the isolation quercetin, quercetin 3,7,4'-triglucopyranoside, quercetin 4'-O-bglucopyranoside and quercetin 3,4'-O-b-diglucopyranoside from the pigmented scales of red onion. Seven flavonols were identified by high-performance liquid chromatography (HPLC) diode array detector coupled with ESI-MS from southern Italian red onions (Bonaccorsi et al., 2005). In this case, quercetin-4'glucoside and quercetin-3,4'-diglucoside were found to be the most abundant components, whereas quercetin-3 -glucoside, quercetin-7,4'-digluco-side, quercetin-3,7,4'triglucoside, isorhamnetin 4 '-gluco-side and isorhamnetin 3,4'-diglucoside were identified as the minor flavonoid components. Furthermore, only trace amounts of free quercetin and isorhamnetin 3-glucoside were detected during this particular study. Although no quercetin diglucosides or quercetin triglu-cosides were isolatedfrom the onion skins used in the current study, a large amount of free quercetin was obtained, as well as a minor amount of quercetin-3-O- $\beta$-Dglucopyranoside. Suh et al. (1999) reported similar results to those of the current study, when they identified quercetin and quercetin 4'-glucoside from onion skins by fast atom bombardment. Suh et al. (1999) also reported the isolation of substantial amounts of isorhamnetin, kaempferol and rutin from onion skins, but only managed to isolate a trace amount of

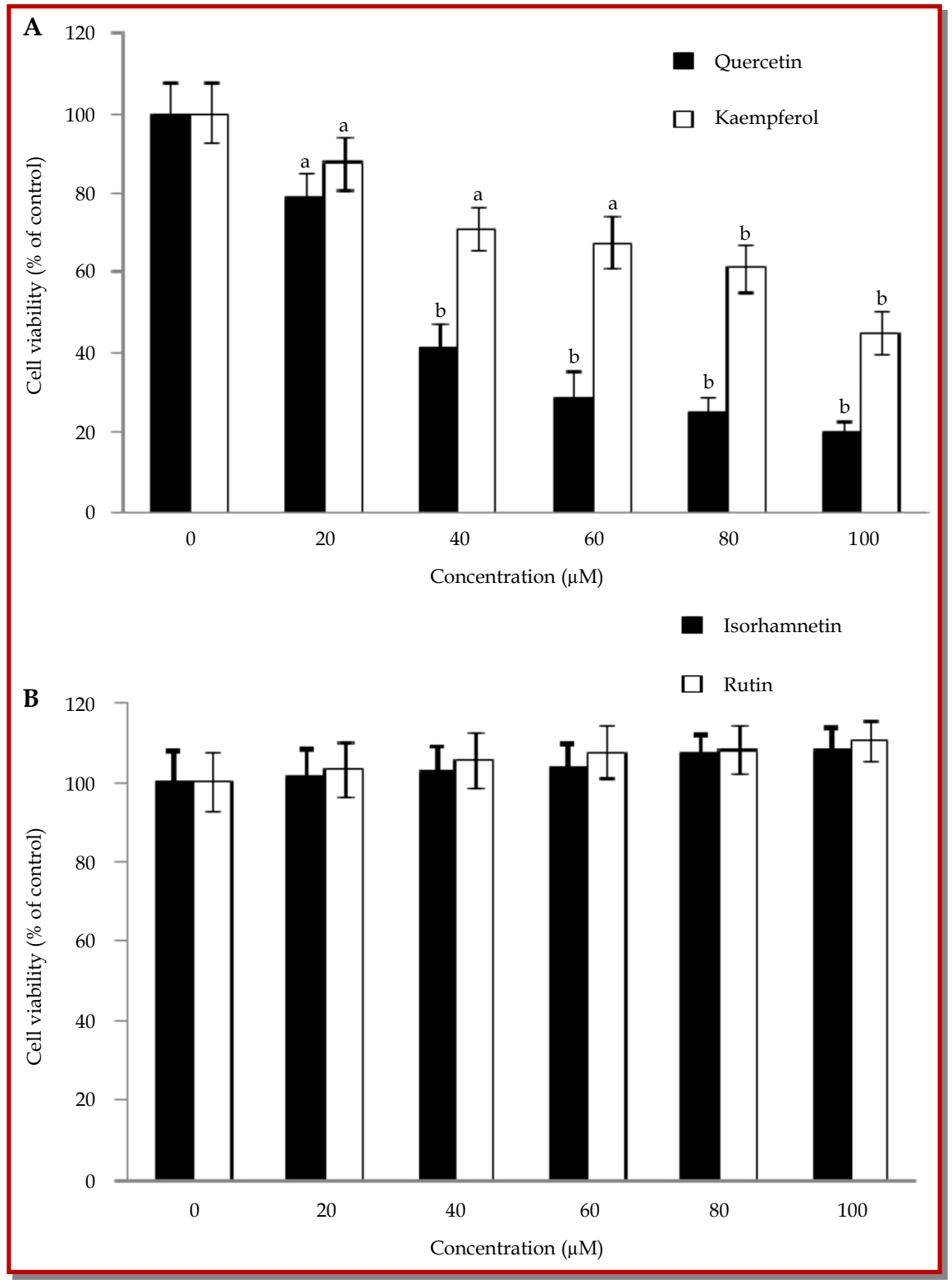

Figure 2: Cytotoxicity of quercetin, kaempferol, isorhamnetin, and rutin on K562 cells

K562 cells were treated with quercetin, kaempferol, isorhamnetin, and rutin at various concentrations for 72 hours, and the cell viability was then determined using an MTT assay. Data are shown as the mean $\pm \operatorname{SD}(n=6)$. ap $<0.05, b p<0.01$ compared with the control 
kaempferol-7-O- $\beta$-D-glucopyranoside. Fur-thermore, no diglucosides or triglucosides of any other flavonols were isolated from onion skins during this study. Taken together, these results suggest that dry onion skins are an abundant source of free flavonols, as well as containing small amounts of flavonol mono-glucosides, and tracequantities of flavonol di- and triglucosides. Rutin was separated from red Spirit onions by sephadex LH-20 chromatography (Park and Lee, 1996). Three major flavonoids, including kaempferol, myricetin, and quercetin, were identified and quantified using the HPLC method developed for the analysis of Georgia-grown Vidalia onions (Sellappan and Akoh, 2002). In the current study, $11 \mathrm{mg}$ of rutin was isolated from $200 \mathrm{~g}$ of dry onion skins, although no myricetin was detected. It is noteworthy that apigenin-7-O- $\beta$-Dglucopyranoside was isolated from onion skins in the current study. It is well known that garlic is an abundant source of apigenin (Miean and Mohamed, 2001). However, to the best of our knowledge, this report represents the first report account of isolation of apigenin-7-O- $\beta$-D-glucopyranoside from onions.

The anti-proliferative effects of flavonoids towards tumor cells are closely related to their molecular structures. In this sense, specific substituents or structural features could be essential for these flavonoids to exhibit specific pharmacological effects (Cárdenas et al., 2006; Shen et al., 2007). Chang et al. ( 2007) compared the effects of 23 different flavonoids on the proliferation of human leukemia HL-60 cells in terms of their structures. The results of this study indicated that an appropriate number of hydroxyl groups, including a hydroxyls at the 3-position and the ortho position of the $B$ ring, was critical to enhancing the inhibitory effects of plant flavonoids towards HL-60 cell proliferation. Plochmann et al. (Plochmann et al., 2007; Kamei et al., 1996) conduced a similar study, and compared the cytotoxic activities of 23 different flavonoids towards the human leukemia cell line Jurkat E6-1. The results of this study showed that the presence of a 4-carbonyl group and an ortho-hydroxyl group on the B ring were important for enhanced cytotoxicity. Furthermore, flavonoids bearing a 3-hydroxyl group were found to be less cytotoxic towards Jurkat E6-1 cells than their nonhydroxylated counterparts. In the current study, quercetin with an ortho-hydroxyl group on its B ring showed greater antiproliferative activity towards K562 cells than kaempferol, while isorhamnetin appeared to enhance the viability of the K562 cells. The weak promotional effect of rutin towards the viability of the K562 cells was attributed to its 3-hydroxyl and 4carbonyl groups being sheltered by the 3-glycoside unit. These effects therefore showed that flavonoids with different structural features can exhibit different cytotoxic effects towards different leukemia cell lines.

\section{Conclusion}

Onion is a suitable source of flavonoids, its quercetin and kaempferol have good anti-proliferative activities on leukemia K562 cell line.

\section{References}

Bonaccorsi P, Caristi C, Gargiulli C, Leuzzi U. Flavonol glucoside profile of southern Italian red onion (Allium cepa L.). J Agric Food Chem. 2005; 53: 2733-40.

Cárdenas M, Marder M, Blank VC, Roguin LP. Antitumor activity of some natural flavonoids and synthetic derivatives on various human and murine cancer cell lines. Bioorg Med Chem. 2006; 14: 2966-71.

Chang H, Mi MT, Gu YY, Yuan JL, Ling WH, Lin H. Effects of flavonoids with different structures on proliferation of leukemia cell line HL-60. Chinese J Cancer. 2007; 26: 1309-14.

Fossen T, Andersen OM. Spectroscopic techniques applied to flavonoids. In: Flavonoids: Chemistry, biochemistry and applications. Andersen OM, Markham KR (sds). New York, Taylor and Francis, 2006, pp 37-142.

Fossen T, Pedersen AT, Andersen OM. Flavonoids from red onion (Allium cepa). Phytochemistry 1998; 47: 281-85.

Griffiths G, Trueman L, Crowther T, Thomas B, Smith B. Onions: A global benefit to health. Phytother Res. 2002; 16: 603-15.

Jin EY, Lim S, Kim SO, Park YS, Jang JK, Chung MS, Park H, Shim KS, Choi YJ. Optimization of various extraction methods for quercetin from onion skin using response surface methodology. Food Sci Biotechnol. 2011; 20: 1727-33.

Kamei H, Kojima T, Koide T, Hasegawa M, Umeda T, Teraba $\mathrm{K}$, Hashimoto $\mathrm{Y}$. Influence of $\mathrm{OH}$ group and sugar bonded to flavonoids on flavonoid-mediated suppression of tumor growth in vitro. Cancer Biother Radiopharm. 1996; 11: 247-49.

Kefalas P, Makris DP. Liquid chromatography-mass spectrometry techniques in flavonoid analysis: Recent advances. In: Antioxidant plant phenols: Sources, structure-activity relationship, current trends in analysis and characterization. Boskou D, Gerothanasis I, Kefalas P (eds.). India, Research Signpost Publication, 2006, pp 69-123.

Kiassos E, Mylonaki S, Makris DP, Kefalas P. Implementation of response surface methodology to optimise extraction of onion (Allium cepa) solid waste phenolics. Innov Food Sci Emerg Technol. 2009; 10: 246-52.

Kim SJ, Kim GH. Quantification of quercetin in different parts of onion and its DPPH radical scavenging and antibacterial activity. Food Sci Biotechnol. 2006; 15: 39-43.

Lee SU, Lee JH, Choi SH, Lee JS, Ohnisi-Kameyama M, Kozukue N, Levin CE, Friedman M. Flavonoid content in fresh, home-processed, and light-exposed onions and in dehydrated commercial onion products. J Agric Food Chem. 2008; 56: 8541-48.

Ly TN, Hazama C, Shimoyamada M, Ando H, Kato K, Yama- 
uchi R. Anti-oxidative compounds from the outer scales of onion. J Agric Food Chem, 2005, 53: 8183-89.

Markham KR, Geiger H. Proton nuclear magnetic resonance spectroscopy of flavonoids and their glycosides in hexadeuterodimethyl sulfoxide. In: The flavonoids, advances in research since 1986. Harborne JB (ed). London, Chapman and Hall, 1994, pp 441-97.

Miean KH, Mohamed S. Flavonoid (myricetin, quercetin, kaempferol, luteolin, and apigenin) content of edible tropical plants. J Agric Food Chem. 2001; 49: 3106-12.

Ning YC. Structural identification of organic compounds and organic spectroscopy. 2 ed. Beijing, Science Press, 2000.

Park YK, Lee CY. Identification of isorhamnetin $4^{\prime}$-glucoside in onions. J Agric Food Chem. 1996; 44: 34-36.

Pérez-Gregorio RM, García-Falcón MS, Simal-Gandara J, Rodrigues AS, Almeida DPF. Identification and quantification of flavonoids in traditional cultivars of red and white onions at harvest. J Food Compos Anal. 2010; 23: 592-98.

Plochmann K, Korte G, Koutsilieri E, Richling E, Riederer P, Rethwilm A, Schreier P, Scheller C. Structure-activity relationships of flavonoid-induced cytotoxicity on human leukemia cells. Arch Biochem Biophys. 2007; 460: 1-9.

Rhodes MJC, Price KR. Analytical problems in the study of flavonoid compounds in onions. Food Chem. 1996; 57: 113-
17.

Sellappan S, Akoh CC. Flavonoids and antioxidant capacity of Georgia-grown Vidalia onions. J Agric Food Chem. 2002; 50: 5338-42.

Shen J, Tai YC, Zhou J, Stephen Wong CH, Cheang PT, Fred Wong WS, Xie Z, Khan M, Han JH, Chen CS. Synergistic anti -leukemia effect of genistein and chemotherapy in mouse xenograft model and potential mechanism through MAPK signaling. Exp Hematol. 2007; 35: 75-83.

Slimestad R, Fossen T, Vagen IM. Onions: A source of unique dietary flavonoids. J Agric Food Chem. 2007; 55: 10067-80.

Soltoft M, Christensen JH, Nielsen J, Knuthsen P. Pressurised liquid extraction of flavonoids in onions. Method development and validation. Talanta 2009; 80: 269-78.

Stochmal A, Piacente S, Pizza C, De Riccardis F, Leitz R, Oleszek W. Alfalfa (Medicago sativa L.) flavonoids. 1. Apigenin and luteolin glycosides from aerial parts. J Agric Food Chem. 2001; 49: 753-58.

Suh HJ, Lee JM, Cho JS, Kim YS, Chung SH. Radical scavenging compounds in onion skin. Food Res Intern. 1999; 12: 659 -64 .

Yao LH, Jiang YM, Shi J, Tomas-Barberan FA, Datta N, Singanusong R, Chen SS. Flavonoids in food and their health benefits. Plant Food Hum Nutr. 2004; 59: 113-22.

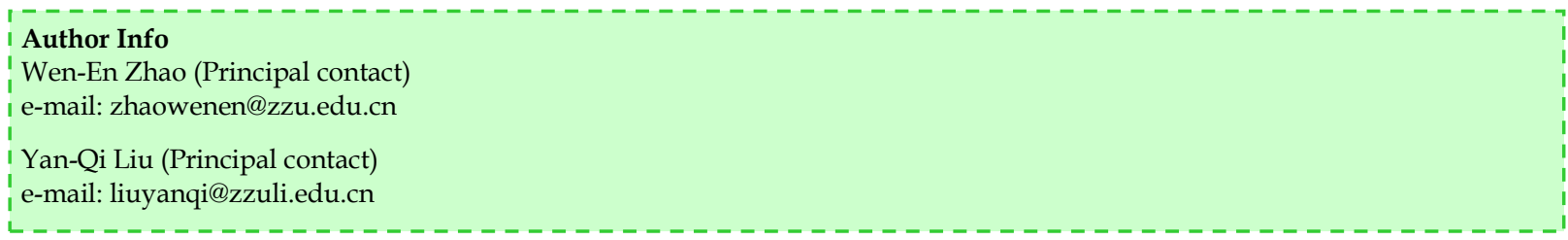




\section{Your feedback about this paper}

1. Number of times you have read this paper 0

2. Quality of paper
Excellent
$\bigcirc$ Good
Moderate
Not good

3. Your comments

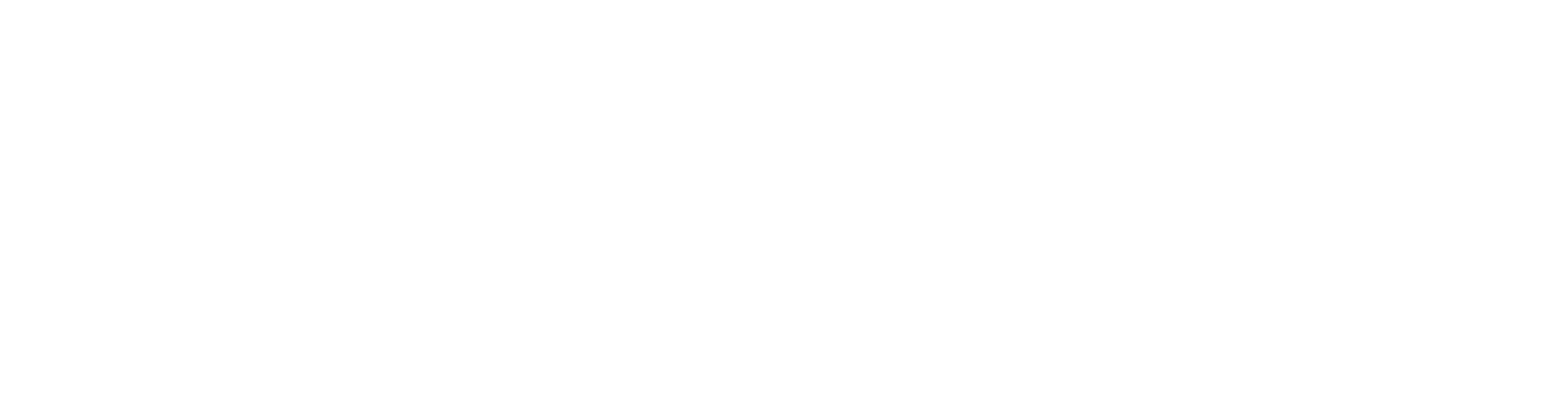

